\title{
PENGARUH PENINGKATAN TEKANAN TERHADAP UNJUK KERJA ENGINE SATU SILINDER
}

\author{
Abrar Riza \\ Program Studi Teknik Mesin Fakultas Teknik Universitas Tarumanagara \\ e-mail: abrarr@ft.untar.ac.id
}

\begin{abstract}
Ignition timing in an important at internal combustion. Timing has a role to synchronize the system in order to get optimal energy. Ignition time is directly related to working pressure in the combustion chamber. The delay combustion will result in higher work pressure. Increased work pressure can increase the performance of the fuel motor and can reduce emissions because combustion is encouraged to be more perfect. Various methods can be done to accompany the conditions of delay combustion to increase work pressure by increasing the octane number. This research focuses on the influence of the one-step gasoline engine performance variable. Effective octane enhancing solutions are used to increase pressure with the concept of combustion delay. Octane-enhancing solutions can be used in various types or concentration in fuel. The results of the study are that torque can increase up to $15 \%$ and the power can increase up to 20\% compared to standard testing conditions. This is effective at medium to high engine speed.
\end{abstract}

Keywords: Delay combustion, increased work pressure

\section{PENDAHULUAN}

Fenomena delay combustion dalam motor bakar sangat menarik untuk diamati, karena melibatkan banyak aspek mekanik, termodinamika dan prinsip combustion. Secara umum delay combustion berhubungan langsung dengan tekanan di ruang bakar, timing pengapian, rasio kompresi, optimalisasi pencampuran bahan bakar dengan udara yang kesemuanya berefek mendorong proses pembakaran lebih baik. Variasi titik pengapian berpengaruh pada tekanan penyalaan atau beberapa derjat dari titik mati atas (top center) pada mesin Otto. Awal pembakaran dan cepat rambat api lebih baik dalam siklus maka kerja akan mennghasilkan menjadi lebih besar. Hal ini karena langkah piston menjadi lebih panjang atau disebut juga delay combustion sehingga meningkatkan torsi [1].

Berdasarkan prinsip termodinamika, efisiensi sistem motor bakar fungsi dari kompresi rasio, naiknya efisiensi dipengaruhi oleh kenaikkan kompresi rasio dan tekanan naik dengan kenaikkan kompresi rasio. Peningkatan tekanan kerja merupakan usaha untuk meningkatkan efisiensi termal. Kondisi padamesin motor bakar, kecenderungan kenaikkan tekanan akan menyebabkan bahan bakar dalam ruang bakar lebih mudah terbakar sehingga meningkatkan kemampuan terbakarnya bahan bakar diruang bakar. Bahan bahan bakar terbakar dengan cepat seperti fenomena knocking serta pada waktu yang hampir bersamaan. Keuntungan maksimum kompresi rasio pada motor bakar berkarateristik penyalaan dengan waktu tunggal atau disebut juga antiknocking. Hal ini dapat bermanfaat disamping meningkatkan efisiensi termal jaga menekan emisi gas buang.

Pertimbangan lain secara termodinamika akibat kenaikan tekanan yaitu kapasitas panas gas naik dengan naiknya temperatur. Proses perpindahan panas meningkat dengan meningkatnya temperatur sehingga dapat menghasilkan pembakaran yang lebih baik, melalui peningkatan perpindahan panas antara gas dalam silinder dengan dinding silinder. Dimana gradien temperatur dan tekanan bersifat irreversibel. Kenaikkan tekanan dapat juga berpengaruh pada sistem mekanisme engine terutama pada valve masuk-keluarnya gas [2]. Khusus pengaruh ini akan diteliti lebih lanjut pada kesempatan berikutnya.

Aspek mekanik terkait dengan singkronisasi gerak crank shaft dengan noken as yang dihubungi oleh timing belt. Radius putar noken as salah satu pengendali lama waktu siklus atau panjang langkah piston.Makin pajang langkah piston maka makin tinggi rasio kompresi sehingga dapat meningkatkan tekanan ruang bakar. Timing pengapian atau derajat pengapian dapat di tunda dengan meningkatkan nilai oktan bahan bakar. Makin tinggi nilai oktan berakibat makin kecil derajat pengapian atau disebut juga delay combustion. Efek dari delay combustion juga 
meningkatkan rasio kompresi atau kenaikan tekanan ruang bakar. Namun kemampuan menaikan kompresi rasio dibatasi oleh dimensi ruang bakar dan kualitas oktan bahan bakar. Variable terkait juga dengan timing valve yang dipengaruhi kecepatan mesin. Kemampuan bahan bakar dikonversi naik jika kompresi rasio naik yang berakibat daya mesin naik [1].

Hipotesis di atas semuanya bermuara pada meningkatnya rasio kompresi. Keuntungan meningkatnya rasio kompresi, dua diantaranya yaitu tekanan ruang bakar meningkat dan pencampuran bahan bakar dan udara semakin baik. Kedua aspek ini dapat mendorong proses pembakaran di ruang bakar makin baik, sehingga dapat mengurangi bahan bakar sisa pada gas buang yang merupakan emisi terhadap lingkungan. Tetapi kelemahan peningkatan rasio kopresi adalah umur mesin menjadi lebih pendek atau biaya material meningkat karena dibutuhkan material ruang bakar yang lebih baik. Peningkatan rasio kompresi dapat mendorong peningkatan efisiensi. Peningkatan kompresi data mempertahankan efisiensi tetap tinggi pada semua tingkat kecepatan dan semua kondisi beban [3].

Secara umum dari hipotesis di atas dengan meningkatkan kompresi rasio dapat menguntungkan. Delay combustion dapat memberikan waktu lebih lama untuk partikel bahan bakar tervaporisasi dan mendorong pencampuran bahan bakar dan udara lebih baik dalam fase gas saat sebelum pengapian [4]. Selin itu, turbulensi juga dapat mendorong pencampuran bahan bakar dan udara sebelum terjadi pencetusan diruang bakar sehingga meningkatkan rambat pembakaran yang berakibat meningkatnya unjuk kerja dalam proses pembakaran [5].

Radiabel yang dapat mempengaruhi delay combustion adalah angka oktan bahan bakar. Angka oktan adalah suatu angka yang menyatakan suatu kemampuan bahan bakar minyak dalam menahan tekanan kompresi. Untuk mencegah bensin terbakar sebelum busi menyala mencegah terjadinya suara menggelitik di dalam mesin bensin. Angka oktan diperlukan karena berhubungan dengan kemajuan teknologi permesinan, yang mempunyai kecenderungan menaikkan perbandingan kompresi untuk meningkatkan power output, yang mana membutuhkan bahan bakar dengan angka oktan yang tinggi. Bilangan oktan diukur dengan membandingkan kecenderungan ketahanan bahan bakar tersebut dalam mengalami memulai proses pembakaran. Maka, penelitian ini bertujuan untuk melakukan analisis terhadap pengaruh peningkatan tekanan ruang bakar yang dipresentasikan melalui angka oktan bahan bakar.

\section{HASIL DAN PEMBAHASAN}

Adapun metodologi penelitian dengan memvariabelkan nilai oktan. Metoda dilakukan dengan mengambil data pengaruh berbagai jenis larutan peningkat oktan dan kedua data akibat pengaruh konsentrasi larutan oktan dengan jenis larutan yang sama. Pada makalah ini hanya dibatasi untuk satu konsentrasi oktan saja yaitu $100 \mathrm{ml}$. Data pengaruh konsentrasi larutan peningkat oktan diambil sebelum menggunakan booster dan sesudah menggunakan booster. Data diambil perubahan kecepatan dengan beban konstan, perubahan torsi dihasilkan dan perubahan laju bahan bakar. Hasil dari data dapat mengeluarkan grafik sehingga dapat dilakukan analisis dari perbedaan yang diperlihatkan.

Variabel pengujian mesin Otto satu silinder menurut termodinamika adalah temperatur dan tekanan serta laju massa akan dijadikan acuan melihat unjuk kerja akibat perubahan tekanan kerja diruang bakar dalam penelitian ini. Pada eksperimen ini variabel yang dapat dicatat adalah putaran mesin, torsi, laju bahan bakar, daya dan efisiensi termal. Variabel ini dapat direkam langsung dan atau hasil pengolahan data. Berikut dicoba dilakukan analisis dengan menampilkan grafik dari variabel-variabel tersebut.

Pengujian unjuk kerja mesin Bensin dengan pengaruh peningkatan tekanan kerja dapat dilihat dari hasil pengolah data yang dapat dilihat pada Gambar 1. Gambar 1 merupakan hubungan antara torsi dengan putaran mesin. Dapat dilihat pada putaran mesin 2100 torsi yang dihasilkan oleh motor sebelum menggunakan octane booster adalah $4 \mathrm{Nm}$ dan setelah menggunakan octane booster torsi dari motor meningkat hingga $0,3 \mathrm{Nm}(7,5 \%)$. 


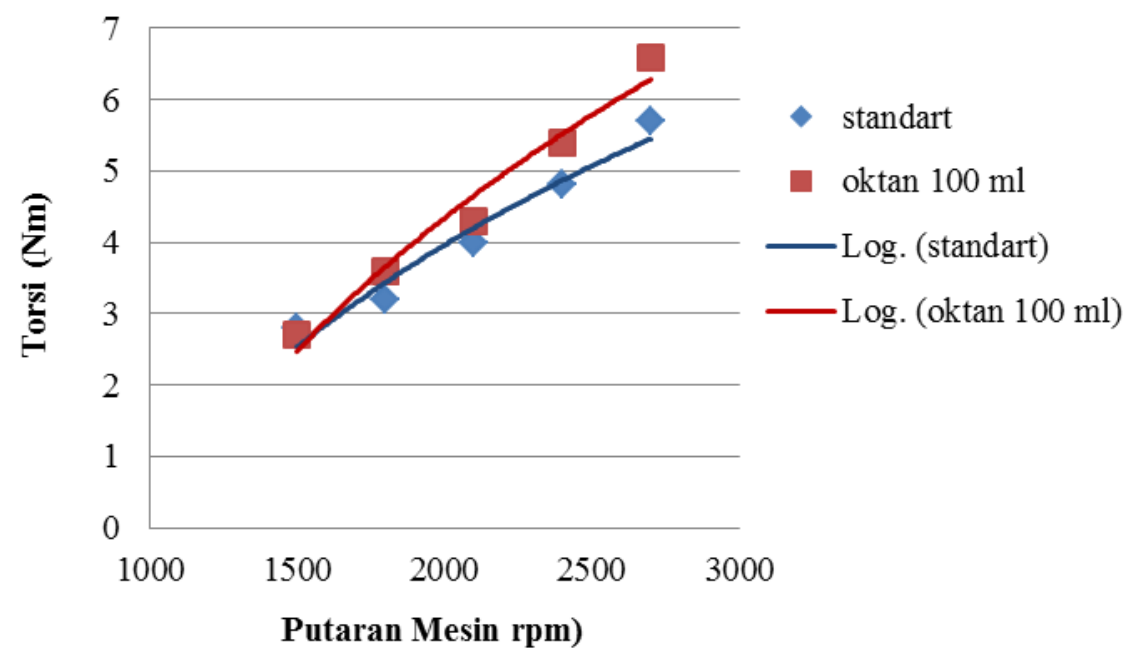

Gambar 1. Torsi dan putaran mesin dengan larutan peningkat oktan kadar100 ml

Diamati pada putaran mesin 2700Rpm, torsi yang dihasilkan sebelum menggunakan octane booster adalah 5,7 $\mathrm{Nm}$ dan setelah menggunakan booster torsi yang dihasilkan adalah 6,6 $\mathrm{Nm}$ terjadi peningkatan torsi sebesar 10,5\%. Hal ini diduga setelah dicampur dengan octane booster, terjadi keteraturan molekul dari hidrokarbon pada bahan bakar, sehingga mempermudah terjadinya tumbukan antara molekul dari bahan bakar dengan oksigen yang berada di sekitarnya. Octane booster pada prinsipnya menaikkan nilai oktan, sehingga derajat pengapian bisa ditingkatkan dan tekanan kerja juga meningkat serta meminimalkan knocking, menjadikan pembakaran sempurna, dan tenaga otomatis akan bertambah.

Pada grafik pengujian antara daya (BHP) dengan putaran (n) dengan menggunakan campuran 10\% octane booster terlihat bahwa octane booster terlihat lebih baik dibandingkan dengan sebelum menggunakan octane booster dan setelah menggunakan octane booster dengan terjadi kenaikan torsi yang baik dari mulai putaran mesin $2.100 \mathrm{rpm}$ sampai pada puncaknya yaitu 2.700 rpm. Dari grafik di atas dapat dilihat pada putaran mesin $2.700 \mathrm{rpm}$ daya (BHP) yang dihasilkan oleh motor sebelum menggunakan 1,61 Kw dan setelah menggunakan octane booster torsi dari motor meningkat hingga 0,14 Nm (8,69\%). Hal ini diduga oleh karena setelah dicampur octane booster yang disusun di dalam booster rangkaian dari hidrokarbon bahan bakar menjadi lemah dan membentuk partikel-partikel kecil yang lebih teratur, sehingga proses pengikatan dengan oksigen menjadi lebih baik.

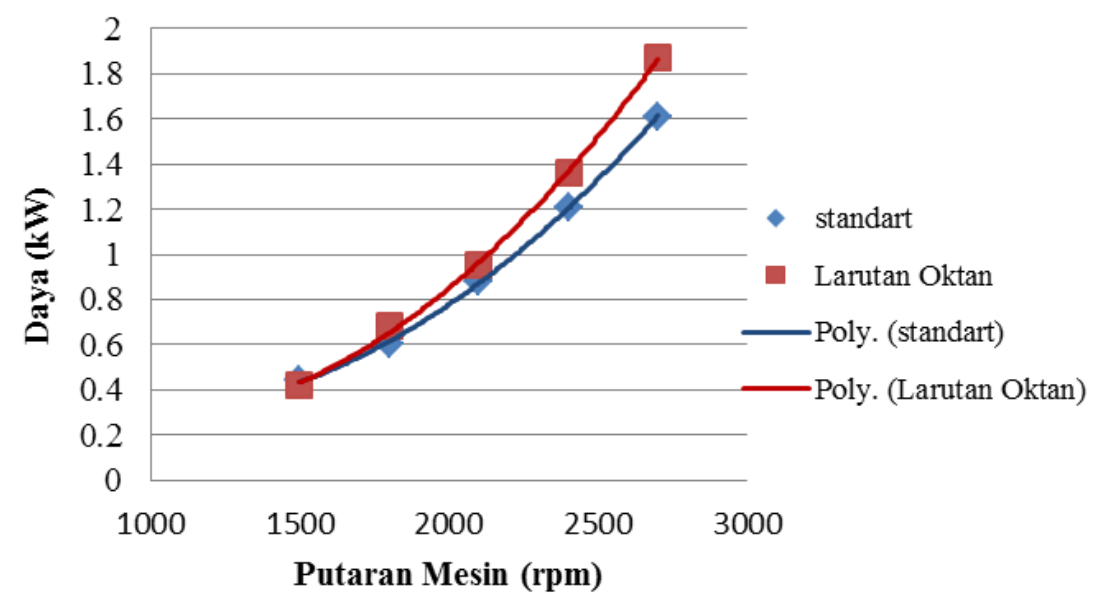

Gambar 2. Daya dan putaran mesin dengan larutan peningkat oktan kadar $100 \mathrm{ml}$

Pada grafik pengujian antara daya (BHP) dengan putaran (n) dengan menggunakan campuran 10\% octane booster terlihat bahwa octane booster terlihat lebih baik dibandingkan 
dengan sebelum menggunakan octane booster dan setelah menggunakan octane booster dengan terjadi kenaikan torsi yang baik dari mulai putaran mesin 2.100rpm sampai pada puncaknya yaitu $2.700 \mathrm{rpm}$. Dari grafik di atas dapat dilihat pada putaran mesin $2.700 \mathrm{rpm}$ daya (BHP) yang dihasilkan oleh motor sebelum menggunakan 1,61 Kw dan setelah menggunakan octane booster torsi dari motor meningkat hingga 0,26 Nm (16,15\%). Hal ini diduga oleh karena setelah dicampur octane booster yang disusun di dalam booster rangkaian dari hidrokarbon bahan bakar menjadi lemah dan membentuk partikel-partikel kecil yang lebih teratur, sehingga proses pengikatan dengan oksigen menjadi lebih baik.

Efisiensi dipengaruhi oleh daya dihasilkan dan laju bahan bakar. Efisiensi termal berbanding lurus dengan daya dihasilkan dan berbanding terbalik dengan laju bahan bakar. Salah satu jalan meningkat efisiensi dengan meingkatkan tekanan dan temperatur kerja tetapi menurun laju bahan bakar. Peningkatan tekanan dan temperatur dapat meningkatkan energi yang dihasilkan tetapi diharapkan selisih energi dihasikan masih lebih tinggi dibanding selisih energi akibat pengurangan bahan bakar. Gambar 3 memperlihatkan efisiensi mengunakan laurutan peningkat oktan kurvanya lebih baik dibandingkan kondisi standar.

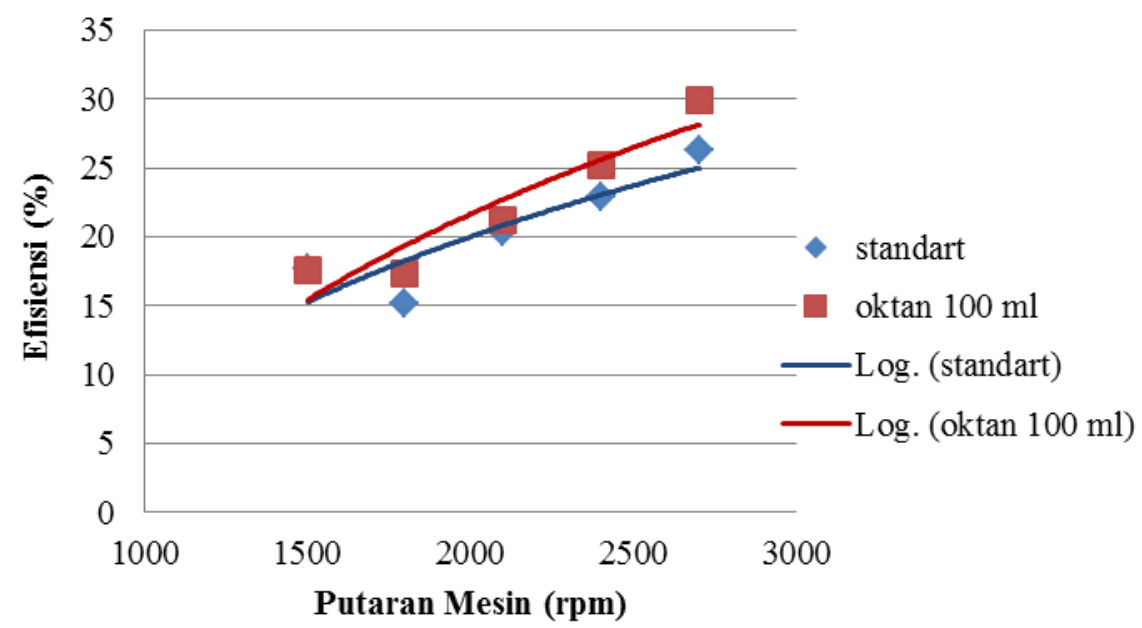

Gambar 3. Efisiensi termal dan putaran mesin dengan larutan peningkat oktan kadar $100 \mathrm{ml}$.

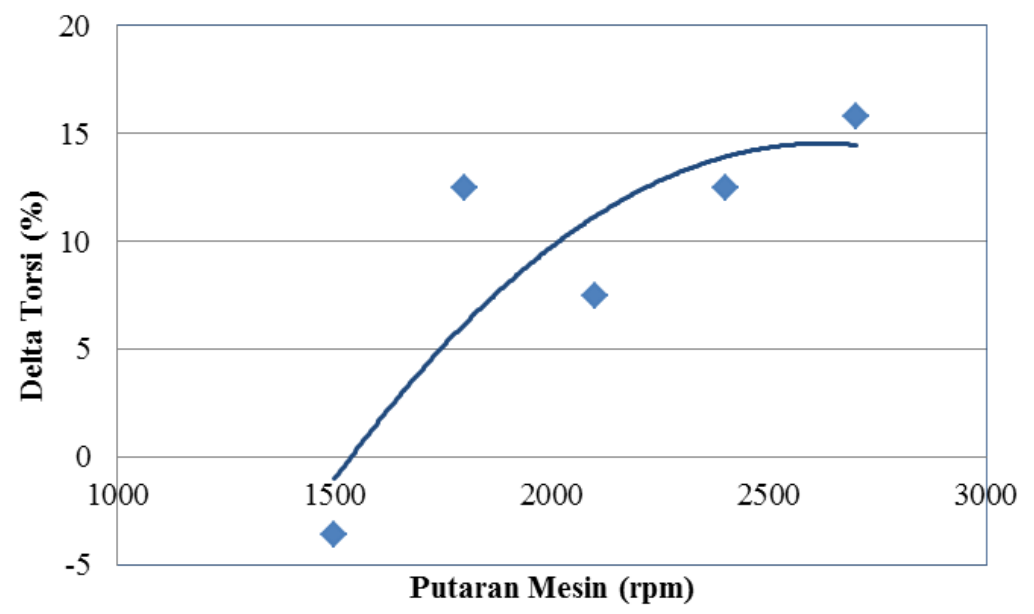

Gambar 4. Delta torsi dan putaran mesin dengan larutan peningkat oktan kadar $100 \mathrm{ml}$.

Penelitian ini dianalisis dengan melihat perbedaan nilai pengujian setelah mengunakan larutan penguat oktan dibanding standar. Selisih tersebut dibagi nilai standar dan dikali seratuspersen. Besaran ini menjadi acuan efek unjuk kerja karena nondimensional, sehingga dapat dibandingkan dengan metoda pengujian yang lain. 


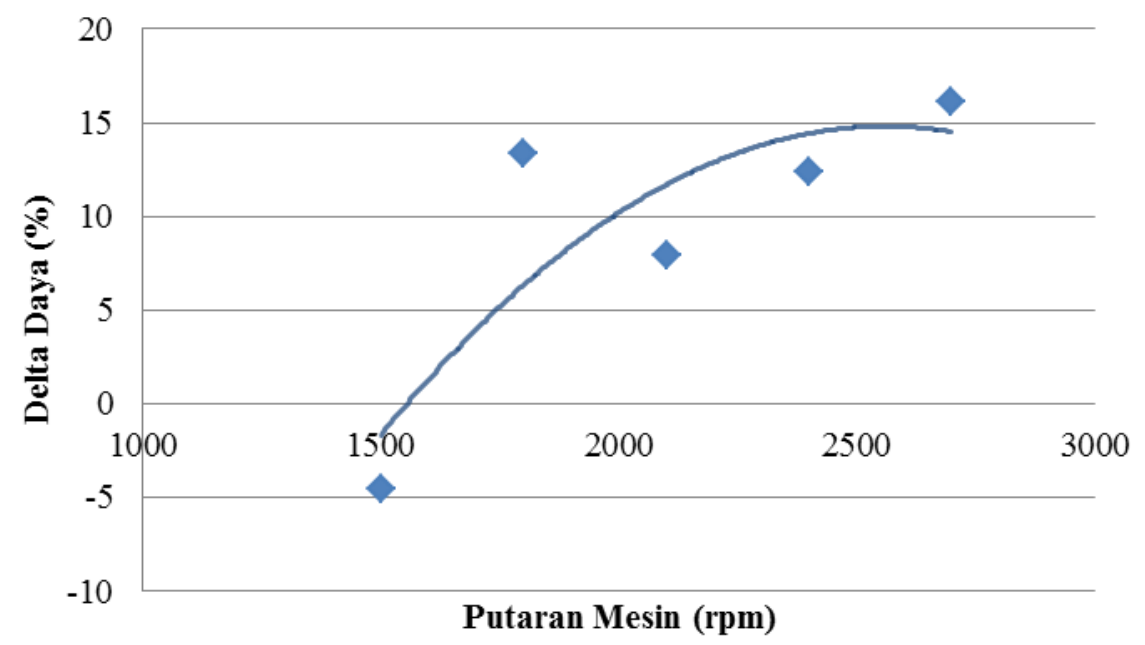

Gambar 5. Delta daya dan putaran mesin dengan larutan peningkat oktan kadar $100 \mathrm{ml}$.

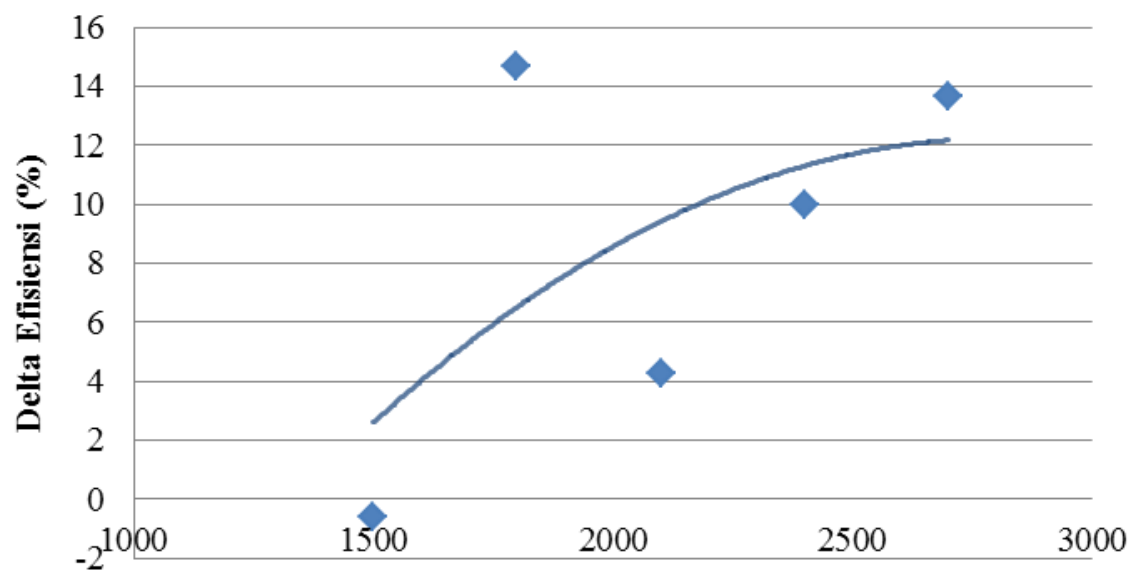

Putaran Mesin (rpm)

Gambar 6. Delta efisiensi termal dan putaran mesin dengan larutan peningkat oktan kadar100 ml.

Tiga variabel yang diamati semua nilai secara umum mengalami peningkatan.Torsi turun pada putaran mesin rendah tetapi terus meningkat melebihi nilai standar. Torsi dapat ditingkatkan jika bahan bakar dicampur dengan larutan peningkat oktan. Hal ini karena larutan dapat meningkatkan nilai oktan yang berefek delay combustion. Delay combustion berakibat rasio kompresi meingkat. Rasio kompresi meningkat tekanan ruang bakar meningkat sehingga energi dihasilkan juga meningkat. Torsi dapat meningkat sampai $15 \%$ dengan mengunakan larutan peningkat oktan yang terjadi didaerah kerja putaran mesin tinggi, dapat dilihat pada Gambar 4 . Perubahan daya hampir sama dengan perubahan torsi. Disini dapat diduga rentang kerja mesin belum melewati kondisi titik torsi maksimum.Daya dihasilkan tersebut dapat dilihat Gambar 5 .

Perubahan efisiensi juga meningkat dengan bertambahnya putaran mesin.Putaran mesin tinggi terlihat pengunaan larutan peningkat oktan makin efektif. Putaran mesin sekitar $2800 \mathrm{rpm}$ peningkatan efisiensi mencapai 14\%, hal ini dapat dilihat pada Gambar 6.

\section{SIMPULAN DAN SARAN}

Larutan peningkat octane booster efektif digunakan untuk meningkatkan unjuk kerja. Larutan peningkat oktan dapat digunakan berbagai jenis dan berbagai tingkatan kadarnya dalam bahan bakar.Torsi dapat meningkat sampai 15,7\% menjadi 6,6 $\mathrm{Nm}$ dan daya dapat meningkat 
sampai 20\% menjadi 1,95 kw dibanding kondisi pengujian standar. Hal ini efektif terjadi pada putaran mesin sedang sampai tinggi.

\section{DAFTAR PUSTAKA}

[1]. Heywood B.J., 1988, “Internal combustion Engine Fundamental” Mc Graw Hill Massachusetts Institute of Technology.

[2]. Borgnakke, Sonntag, 2009, "Fundamentals of Thermodynamics”, John Wiley and son Inc. Minchigan USA.

[3]. Rebeiro dan Martins, 2006, Jurnal SAE International 2007-01-0261, Mechanical Engineering de Minho Fortugal.

[4]. Thomas F Sanchez, 2008, "Experimental Study of a Kerosene Fuelled Internal Combustion Engine” Theses Master, Polytecnique Federale de Lausanne Fortugal.

[5]. Ganesan V., 1996, "Internal Combustion Engine” Mc Graw Hill USA. 